\title{
Introduction
}

AT THE turn of the century the subtropical territory of Misiones, in northeastern Argentina, was a frontier region, not only by virtue of its location between Brazil to the east and north and Paraguay to the west, but also, and especially, because it was a land of pioneers, somewhat like Alaska and the Yukon at the same moment in the history of North America. It was populated by aboriginal natives, mestizos, blacks, and whites; by Argentines, Brazilians, Paraguayans, and foreigners from abroad; by speakers of Guaraní, of Spanish and Portuguese, and of a number of later immigrant languages from Europe. The zone was-and remains-important for its forest products, and above all its yerbales or plantations of yerba mate, the green tea especially favored in Uruguay, Argentina, Paraguay, and southern Brazil. Such plantations were first established by the Jesuits in the early seventeenth century, as a major economic venture of their reducciones (collective settlements) of Guaraní natives, which flourished till the company was expelled from the Spanish dominions in 1767. It is of course the missions they founded which gave Misiones its name.

This is the setting of almost all of the most celebrated stories of Horacio Quiroga, including those selected for the present volume-excepting the lead story, "Beasts in Collusion," which is set in the Brazilian Mato Grosso to the north. They are tales of risk and danger, suffering, disease, horror, and death; but also of courage and dignity, hard work, and human endurance in the face of hostile nature and the frequent brutality of men. In most of the stories translated here (all but two appearing in English for the first time) there are piquant touches of humor and bemused irony as well.

Our title, The Exiles and Other Stories, echoes that of one of Quiroga's own volumes, Los desterrados (1926), often said to be his best book. Included here are five stories from that collection, seven written earlier (1908-1923), and one subsequently (1929). This latest tale, "The Forerunners," picks up a theme introduced in the title story, "The Exiles," and is one of five that present characters who appear in more than one story. All thirteen are similar in inspiration, and may be said to constitute a kind of loosely structured, episodic novel-along with some of those published in The Decapitated Chicken and Other Stories (Austin: University of Texas Press, 1976), especially "Drifting," "A 
Slap in the Face," "In the Middle of the Night," "The Dead Man," and "The Son." These stories are held together by common themes, situations, and conflicts-and of course their common setting in Misionesbut most of all by their vision of man (of men and women) in that setting, including Quiroga himself, who appears in various guises, and according to A. H. Rodríguez "made of himself the best character in his work" (El mundo ideal de Horacio Quiroga, $3^{\mathrm{a}}$ ed. [Posadas: Montoya, 1985], p. 47).

Quiroga has been compared to our own Jack London, his contemporary and fellow-practitioner of a characteristically New World type of fiction. But he was far less ideological and political than London, more bourgeois in origin, better educated, and more literary as a youth, having published before he was twenty and edited the Revista de Salto before his trip to Paris at twenty-one (1900). His formative years coincided with the apogee of the estheticist modernista movement in Spanish American literature (Rubén Darío arrived in Buenos Aires in 1893, and stayed till 1898), and his first two books $(1901,1904)$ betray its influence, as well as that of Charles Baudelaire's exemplar, Mr. Edgar Allan Poe. At this time his interest in the dark side of life was still largely literary, though he had already suffered the death of his father, his stepfather, and a close friend (see "A Quiroga Chronology" at the end of this volume).

When he discovered Misiones, Quiroga apparently found a world free of the constraints of urban life, where he could forge an existence in accordance with his own designs. He was of course not a primitive, but a sophisticated modern who brought culture and technology to the wilderness. He had books, all sorts of tools, and even a Model T, the latter a decided rarity in the Misiones of that day. From 1903 on he would spend about half his time in the north (including the Chaco, Corrientes, and Paraguay as well as Misiones) and half in Buenos Aires, where he would continually long for the home he had built with his own hands, overlooking the Paraná near San Ignacio (see map, p. 152). He had become a successful writer in the city, and did not need to struggle in Misiones, but that was where he wanted to be, where he felt he belonged. No doubt it was his destiny to confront life in its most basic forms, and to exploit the openness of the frontier, both directly, in his manual labor, and literarily, in his fiction. Though the urban Quiroga will always be remembered for such gripping tales as "The Decapitated Chicken," it is in Misiones that he finds his truest and 
most authentic voice. And his intense feeling for the land and its people is unmistakable. Even a quasi-mystical communion with nature is detectable at times.

Quiroga's characters are a varied lot. In this book we find parents and children, servant girls, prostitutes, laborers, foremen and overseers, craftsmen, shopkeepers, landowners and lumber barons, river sailors, scientists, derelicts and drunks, and even union organizers. Some characters are mestizos, or creoles of European stock. Many others are immigrants: from Sweden, Holland, Belgium, and England; France, Spain, and Italy; Germany, Poland, Hungary, and Turkey. Like the United States, the River Plate region was a land of opportunity in those days, and the influx of immigrants was very large, especially as compared to the number of native-born. (In 1914 there were about a million Italians-to say nothing of other immigrants-living in Uruguay and Argentina, out of a total population of about nine million.) Though a few of Quiroga's foreigners ultimately break under the strains of life in their harsh new environment, almost all are hard workers, like most of the creoles and indigenas who live beside them.

Work, indeed, is a central concern in these stories. There are contract laborers (mensualeros or mensús) who slave for months under cruel supervision, only to splurge their advances on a week's orgy in Posadas and return to the hazards of tropical fever, brutality, and death in the lumber camps. There are peones and household servants who work for short-term wages and are likely to walk off and disappear as quickly and unexpectedly as they first came on the scene. A number of workers are fierce independents who will commit themselves to just one task at a time in order to maintain their freedom from bosses. Others are small entrepreneurs who pluck logs from the river, try to grow crops, or establish cottage industries like cooking charcoal or the distillation of liquor from oranges. And finally, in "The Forerunners," we have the tragicomic story of the field hands on the yerba plantations and the first frustrated efforts to build their labor union.

Quiroga is no socialist, but his stories clearly reveal his sympathy for the victimized mensús and plantation workers and other peones subjected to the barbarities of cruel bosses. He does not lecture, but simply describes conditions as he finds them. He shows little interest in the class struggle but, as befits a writer of fiction, a great deal of interest in individuals. Their skills impress him, and he admires their 
strength and persistence in the face of adversity. (Many of his characters are closely modeled on persons he actually knew in Misiones.) His ethic of work may be viewed as a kind of metaphor for human dignity.

Our author's material is regional and local, and in this sense he is a criollista or nativist. But he is seldom merely picturesque. While his characters and their circumstances are authentic, and he sometimes presents their activities in considerable detail, he is much less concerned with documentation than with basic human problems: survival, taming nature, confronting injustice, raising and protecting children, mastering difficult tasks, rising to creativity-and showing compassion for those who fail and suffer, through weaknesses of their own or the villainy of others. The focus is characteristically Hispanic in that the psychological is far less important than the existential. In some of his urban stories Quiroga displays an interest-inherited at least in part from Poe-in abnormal mental states, but here, in Misiones, his concern is man among men, especially man in conflict-and sometimes in harmony - with nature. (A marginal exception is that of alcoholism, particularly in the case of Dr. Else in "The Orange-Distillers.")

Quiroga is probably the most important precursor of the so-called "Boom" in Latin American fiction, which coincided, roughly, with the third quarter of the twentieth century. In recent years the names of Borges, Carpentier, Cortázar, Sábato, Bioy Casares, Onetti, Donoso, Fuentes, Rulfo, Vargas Llosa, Cabrera Infante, Nobel prizewinners Miguel Angel Asturias and Gabriel García Márquez, and a number of others, have become internationally familiar, and justifiably so. But they did not emerge from the void; the ground had been prepared, by Quiroga and some of his contemporaries, who were able to shed much of the artificiality, inflated rhetoric, and polemical tendentiousness, as well as many of the normative conventions (largely derived from European literature) of early twentieth-century fiction in Latin America. Their work became less shallow, less programmatic, less extraliterary in purpose. Quiroga in particular began to treat the more deep-seated, more central aspects of human experience-and to do so concretely, in strictly American terms. That he succeeded is shown most obviously by the fact that he is still widely read and appreciated, not only within but also beyond the Spanish-speaking world-indeed that his reputation has grown, his work now receiving increased attention from critics and literary historians.

But as a transitional figure he could hardly have risen to the formal mastery of a Borges, a Cortázar, or a García Márquez. He is not a 
great prose stylist, though his means, by and large, seem adequate to his purposes. Some of his weaknesses are evident in the melodramatic and somewhat heavy-handed (but nevertheless powerful) "Beasts in Collusion," which he did not include in any of his books. A number of his stories lack a clear center, sharing two or more prominent themes, such as "The Charcoal-Makers" and "The Exiles." Others wander from one incident to the next, like "A Workingman." There are occasional small inconsistencies of detail, imprecisions of syntax, and more often lapses in semantic rigor. But there are just as many stylistic felicitiessuch as the control of substandard dialect in "The Forerunners"-and the whole is vivid, convincing, and oddly profound. Furthermore, the stories of Misiones present a coherent world-view, a kind of creole tragic sense of life, ranging from pure horror to the anthropological irony of "The Contract Laborers," "The Log-Fishermen," "A Workingman," "The Exiles," "The Forerunners," and others. Quiroga remains unique, apparently inimitable.

He wrote about two hundred short stories, and at least a third of them remain memorable. He thoroughly understood the genre, and exploited almost all of its possibilities, including the fantastic, a mode generally restricted to his urban stories, and only tangentially represented here (most clearly in "The Yaciyateré"). For rather complicated reasons, including the decline of Hispanic prestige in Europe after 1588 , he is less well known than some of his peers (and freely acknowledged masters), such as Poe, Maupassant, and Chekhov. But he is in the same class as they, even in his unevenness, and his best work belongs not only to Latin America, but the world.

We have mentioned his attachment to Misiones. But perhaps only a visit to that land can convince one of its immense attractiveness: its rich red earth, its forests and yerbales, its magnificent falls on the Iguazú, its remote towns and villages, the resplendent jacarandás along the streets of its lovely capital, Posadas-and above all the majestic river, Olivera's "devil of a Paraná" ("A Workingman"), which defines its long border with Paraguay. These stories, whatever their incidents and conflicts, whoever their characters, are preeminently tales of Misiones, their narratives compenetrated with Misiones, its trees and waters, its climate, it agriculture, its people. San Ignacio's Jesuit ruins and Quiroga's house outside town have been cleaned up now, for the tourists, but readers of his tales can still picture them as they were more than sixty years ago, when Dr. Else mistook his daughter for an enormous rat. Because sense of place is so important in Quiroga, and 
because most readers in our distant climes will never see Misiones, I have thought it important to provide a map, and a list of place names, which follow the text. (But if you can, take a plane to Rio, and continue on to Foz-do-Iguaçu. Cross the new bridge to Argentina, and take a long bus ride south, down through Misiones to Quiroga country.)

In these translations I have not attempted to improve upon Quiroga, nor to drag him out of his context and into Anglophone literature. I have tried to stay close to his Spanish, to avoid dipping too far below the surface in search of his underlying meaning. In the process I have no doubt stretched the capacities of English a bit, but intentionally, in the conviction that a translation should not conceal its origin, not read as though written directly in the receptor language, but rather exploit the rich possibilities of the bilingual encounter, while respecting the norms of that second language. In so doing I hope I have conveyed something of the special flavor of Quiroga's prose, which like Quiroga himself is suigeneris.

J. D. D. 


\section{THE EXILES}

and Other Stories 